\title{
The Inflow of Southeast Asian Health- care Worker Candidates in Japan: Japanese Reactions to the Possibility of Cultural and Ethnic Diversity
}

\author{
KENJI KANEKO
}

\begin{abstract}
This paper examines the social and cultural meanings of the incorporation of Southeast Asian healthcare migrant workers in Japan, focusing in particular on Japanese attitudes and perspectives. I argue that several issues and concerns are related to the way the Japanese see Japan as a homogeneous society, and that these issues and concerns intertwine with Japan's historical experience of the inflow of non-Japanese migrants. The arrival of Southeast Asian healthcare workers has been met with concern in Japanese society, but because of its rapidly aging and shrinking population, Japan's healthcare industry needs to internationalize. The article is based on research data that includes information on events, debates and arguments in official and unofficial documents, newspaper articles and transcripts of interviews in the press in both Japanese and English. It aims to provide a better understanding of how Japan is tapping into the international labour market to bolster its health industry. The situation of Southeast Asian healthcare migrant workers in Japan is also examined in its historical, social and cultural contexts.
\end{abstract}

Keywords: Globalization, Japan, national identity, aging, shrinking population, Southeast Asian healthcare workers

\section{Introduction}

This article will examine discourses regarding Japan's globalization through the incorporation of global migrant workers, particularly for nurses and caregiving workers from Southeast Asian countries under free trade agreements: the Japan-Indonesia Economic Partnership Agreement (JIEPA), Japan-Philippines Economic Partnership Agreement (JPEPA) and Japan-Vietnam Economic Partnership Agreement (JVEPA). I am particularly interested in discovering the social and cultural meanings of the incorporation of Southeast Asian healthcare migrant workers in Japanese society. This article aims to provide a better understanding of Japanese reactions to increasing ethnic and 
cultural diversity, and attempts to address two key questions: what issues, concerns and interests emerge for the Japanese, and what are Japanese reactions to the possibility of the nation's ethnic and cultural diversity?

Southeast Asian healthcare migrant workers who have come to Japan are still a tiny proportion of the population, but they may play an important role in caring for Japan's rapidly aging population, providing much-needed assistance for those seniors who cannot perform the activities of daily living, alongside Japanese workers (e.g. Furukawa et al. 1996: 107-143).

In this article, I examine the incorporation of Southeast Asian healthcare migrant workers into Japanese society, which is shaped by an ideology and culture that is rooted the nature of historical, communal and social ties between individuals and their society. ${ }^{1}$ Japanese culture, especially in terms of supposedly ancient traditions, is an important aspect of Japanese society. I argue that this also intertwines with the history of the inflow of non-Japanese migrants into Japan. This inflow has in turn helped shape the nation's identity among Japanese individuals, and those who do not share the nation's identity or know Japanese culture tend to be treated differently in Japanese society (Oguma 1995).

Under the bilateral agreements, Japan and its Southeast Asian counterparts promise to enhance and increase the mutual flow of goods, services, investment and human resources. Nurses and caregiving workers are carefully selected to work in Japan by Japanese government staff. New arrivals are still considered to be 'candidates' because they need to go through training at Japanese hospitals, retirement homes or other healthcare facilities, learn to follow domestic regulations along with Japanese nurses and caregivers, and pass the Japanese-language based examination before being fully employed (Cortez 2010: 193).

The incorporation of international workers is seen as a part of Japan's process of globalization. Globalization emerged as a new and important factor in Japan's long period of economic stagnation since the beginning of the 1990s, and the term guröbaruka (globalization) has become popular among many Japanese. ${ }^{2}$ The popular idea of gurōbaruka is related to ideas that Japan needs to open its door to the outside world, implying mutual dependence between Japan and other countries in which increasing inflow of goods, capital, information and people should become more frequent. But gurōbaruka has also led to mixed reactions within Japan, and there has been increasing concern 
about how Japan should approach a competitive, globalizing world, as well as apprehension about the way that globalization would lead to ethnic and cultural diversity. It is feared that Japan's culture and long-standing traditions may need to be modified or even given up. In particular, not all Japanese are keen to see the expansion of the foreign or non-Japanese population in Japanese society because it might disturb social and cultural harmony (Brody 2002; Herbert 1996). In this sense, the incorporation of international migrants into Japan tends to be seen as an ideological threat to Japanese society.

This article is based on a data collection that includes information on events relating to Japan's use of the international labour market to bolster its healthcare system, as well as related debates and arguments in official and unofficial documents, newspaper articles and transcripts of interviews in the press in both Japanese and English. First, I address the concept of the Japanese family system, the Japanese ideology of homogeneity, and the slow process of Japan's incorporation of international migrant workers. This is to explain why Japan has been hesitant or remained uncommitted to having long-term migrant workers from abroad.

Second, this paper will examine the situation of Japan's healthcare industry. According to the statistics bureau of Japan's Ministry of Internal Affairs and Communications, 25.7 per cent of the total population of Japan was over the age of 65 as of July 2014. ${ }^{3}$ There has also been a downward trend in Japan's working age population and this has caused a constant shortage of workers in the healthcare industry (Takumi 2014: 65). With this concern, some Japanese politicians, intellectuals and economists have begun to support the expanded importation of foreign migrants as a possible solution.

Lastly, this paper will look for social and cultural meanings attached to Southeast Asian healthcare worker candidates, through an examination of a cohort of Indonesian caregiving worker candidates in 2012. They were the first group who spent the mandatory three years (2008-2011) in training in Japan, and the first to take the examination in Japanese. What were Japanese reactions to hosting them? My research has shown that there was cultural apprehension among Japanese hospital workers, patients and their family members during the training period, because it was felt that Southeast Asian healthcare workers would not get along with Japanese patients. This apprehension ceased when it became clear that only a few were able to pass the national exam and start work in the healthcare industry. 


\section{Japan's Ideology of Homogeneity and Inflow of Non- Japanese Migration}

This section looks at non-Japanese in Japanese society, arguing that because of the concept of the Japanese family system, supported by the popular nihonjinron (theories of Japanese-ness), Japan's progress in the incorporation of foreign migrants into the domestic labour market has tended to be delayed. ${ }^{4}$ Whether or not Japan should globalize is an ideological dilemma that presents a choice between liberal, global views and conservative nationalist views regarding Japan and its relations with the outside world, including the incorporation of international migrant workers into Japanese society.

Joy Henry explains that the Japanese family system reflects the continuity of the house or ie (Henry 1995: 24). The concept of the Japanese family system originates from the ideological position of the Emperor during the Meiji period, when all Japanese individuals were considered to be descendants of the Emperor (ibid.: 8-9, 23). At an ideological level, the concept of the Japanese family system was acknowledged as the traditional model of Japanese society for 'the maintenance of orderly social life', but for some Japanese intellectuals, it has been viewed as 'a major hindrance' in the process of Japan's modernization (ibid.: 23; Oguma 1995). The concept of the ie was an important characteristic of a Japanese household, in which it set its own rules and created its own customs. Those who joined an established household, like a spouse, were expected to follow these rules and customs of the $i e$ in order to be accepted as a family member (Henry 1995: 24-26). Although the concept of the Japanese family system was formally abolished in 1947, and has been disappearing in Japan due to the fact that younger Japanese families choose to live as nuclear families, the principle has remained prominent in the ideals of some Japanese people (Henry 1995: 29).

The construction of the Japanese ideology of homogeneity is shown in the way many Japanese are particularly interested in their own culture, seeing and discussing Japan as a unique nation with distinctive characteristics. ${ }^{5}$ To emphasize the uniqueness of one's nation is not unusual but, in the case of Japan, hundreds of publications were released, particularly in the 1970s, and academics, journalists and other influential figures not only discussed the uniqueness of Japan but also developed a theory to explain how 'special' Japan is (i.e. the development of nihonjinron). Kosaku Yoshino suggests that these Japanese 
intellectuals and elites such as educators and businessmen tend to emphasize to students and employees the importance of Japanese culture through education and work (Yoshino 1992: 112-125 and 130-140). This has in turn led to the construction of modern Japanese identity. Thus, the incorporation of international migrants into Japan tends to be seen as an ideological threat to the family system.

In addition, this idea is related to the Japanese notions of inner/outer (uchi/soto), front/back (omote/ura), and on-stage/off-stage (tatemae/ honne) (Rosenberger 1992: 69). These binaries signify whether a Japanese individual should express or not express their thoughts when in public or private, depending on whom they are talking to. The Japanese often acknowledge themselves as an inner uchi group, supported by the idea of Japanese identity in relation to the non-Japanese or foreign 'Others' as an outer soto group in the system of thought. For the Japanese mentality, this serves to create a type of social and cultural boundary between Japan and the outside world. Any discussions about the incorporation of international migrant workers, i.e., soto people, into Japanese society tends to become an on-stage tatemae communication among Japanese conservative nationalist officials, members of the business elite and other influential figures.

I argue that Japan was slow and hesitant to allow labour migration due to its ideology of homogeneity and other insular ideas from the 1970s through to the 1980s. Looking at the changing population of non-Japanese in Japan prior to the 1990s, there were relatively small numbers of non-Japanese, slightly over 0.8 million, or less than one per cent of the total population, in the early 1980s (Taguchi 1983-1984: 701702). But this trend changed in the 1990s. Delaying the importation of foreign migrants in the 1970s has had a serious impact on the lives of the Japanese in today's Japan: it led to a constant shortage of domestic labour in some sectors of the economy.

Why did Japan not incorporate foreign migrants in the 1970s? I will attempt to answer this question by reviewing arguments for sakoku (closing the country) and kaikoku (opening the country) in the 1970s. This debate was associated with the ideology of homogeneity and with the concept of nihonjinron, creating an imagined place in the international system in which Japan was different from any other nation. The presence of foreigners created an ideological problem, the contradiction between an imagined homogeneous Japan and the increasingly multicultural reality. 


\section{The Sakoku and Kaikoku Debate}

The process of globalization in post-war Japan has been a site of contestation between the rival ideologies of sakoku and kaikoku. There has always been a group of nationalist policymakers, scholars and influential figures who believe that Japan should focus on the importance of internal communal unity and domestic issues, and that it would even be better to isolate Japan from the rest of the world, using a sakoku ideology. The term sakoku originates from the conditions in pre-Meiji Tokugawa Japan, when Japan did not have official political and economic relations with other countries, except for China, Korea, Okinawa, and the Netherlands, with whom the Japanese dealt in designated ports. Thus, Japan was not in fact completely isolated. Japan's sakoku was mainly used by the Tokugawa government to maintain a monopoly in international trade, and to reduce the influence of Christianity. But the term, sakoku, has remained as a symbol of Japan's period of isolation. On the other hand, there have been proponents of kaikoku, groups and individuals who support Japan's internationalization. These tend to have a vision of Japan developing as it did during the Meiji period, when the country internationalized through the incorporation of advanced technologies and knowledge from the West.

Post-war Japan's sakoku and kaikoku arguments mainly began in the late 1970s and 1980s. I argue that most isolationist sakoku thinkers shared their view of Japan with nihonjinron thinkers, viewing Japan as an ethnically homogenous society. From their perspective, the inclusion of foreign migrants would harm Japan's cultural purity and disturb social harmony. If Japan accepted foreigners, they would likely become an economic underclass. At that time Japan was the only Asian economic superpower, a status that was accomplished with the help of Japan's ethnic pride. It was thought that Japan's strong work ethic could only be protected by the Japanese, and would be tainted by foreigners. The inclusion of low-skilled foreign migrants might even decrease Japan's total productivity (Brody 2002: 36-38). The incorporation of unskilled and low-skilled foreign workers would be the same as allowing Japanese industries to fall behind. But they overlooked the fact that undocumented foreign migrants had already been in Japan for a while, as part of the domestic labour force in small and medium manufacturing and construction industries.

On the other hand, the global kaikoku thinkers were more interested in relaxing Japan's immigration policy as they saw Japan as a member 
of the international community. It would be more appropriate and sensible to follow international norms and regulations regarding undocumented foreign migrants as the existing immigration policy did not give the government authority over their working conditions and they were often vulnerable to exploitation and human rights violations (Brody 2002: 38-39).

But both the sakoku and kaikoku thinkers agreed that a large influx of foreigners would likely disrupt social harmony, because they imagined that most Japanese were not used to foreigners. However, Brody points out that the critical difference between the sakoku and kaikoku thinkers was their assumptions concerning Japan's tolerance of the presence of foreigners in Japan (2002: 40). The sakoku thinkers argued that Japanese society could not handle a large number of foreigners, while the kaikoku thinkers had more confidence in Japan's ability to tolerate the arrival of foreigners, as long as there were appropriate facilities and institutions for creating smooth and effective social integration.

I also suggest that the sakoku and kaikoku thinkers were bound to their particular images of Japan as a homogeneous society. Interestingly, neither group discussed the large influx of foreign subjects into mainland Japan from the late 1930s to 1945, when over two million Koreans arrived in Japan as an alternative labour force while Japanese soldiers were overseas fighting. This suggests that the sakoku and kaikoku debate did not fully address the real issues. The debate reinforced the hegemonic concept of nihonjinron as it blotted out the memory of the large population of Korean migrants, as if it was a shameful episode in Japanese history.

\section{Foreigners in Contemporary Japan}

After the revision of the 1990 Immigration Control and Refugee Recognition Act, the Japanese government expanded the number of authorized statuses for foreigners from 18 to 27 , to regulate a greater influx of foreigners with different types of visas. However, there was no specific employment status for low-skilled foreign migrants. While the Japanese government hesitated to incorporate low-skilled foreign migrants, there were still vacancies in the agricultural, manufacturing and construction industries.

There were around 2.08 million registered foreigners living in Japan as of July $2014 .{ }^{6}$ This figure has increased for the last three decades, but it remained a small proportion of the total population of Japan (at 1.6 
per cent of 127 million). The largest group of registered foreigners, the Chinese (including those from mainland China, Hong Kong, Taiwan and the zainichi Chinese), accounted for 649,000 people or 31.0 per cent of the total population of registered foreigners. The term zainchi refers to non-Japanese individuals staying in Japan, and most of them came to Japan as cheap labours during the 1930s. The group comprises of Chinese, Koreans and others: the majority of them are Koreans (Sugimoto 2010: 202-209). Over the years, the group has become the largest minority group consisting of second, third, fourth and fifth generation residents. They remain to be non-Japanese, distinct from Japanese nationals, although most of them have been assimilated into Japanese culture. The Chinese were followed by the Koreans (from both the South and North, and including the zainichi) with 509,000 people or 24.0 per cent; the Filipinos with 214,000 people or 10.0 per cent; and the Brazilians with 178,000 people or 8.0 per cent of the registered foreigners. ${ }^{7}$ The Korean population had been the largest foreign population for many decades, but the Chinese population has surpassed it in recent years. While the population of the Korean community in Japan has been aging just like the Japanese population, the Chinese population in Japan has increased ten-fold. This significant rise of the Chinese population could be linked to Japan's greater economic ties with China (Chen 2008). ${ }^{8}$ Many of them come to Japan as university or language students or technical trainees, and some choose to stay and work in Japan. Brazilian returnees have also created a large population since the beginning of the 1990s (Tsuda 1999). ${ }^{9}$ As descendants of Japanese migrants to Latin America, the nikkeijin returnees were selected to become labourers, as most Japanese policymakers assumed that Japanese-Brazilians would fit more easily into Japanese society. The nikkeijin were known by the Japanese to maintain Japanese heritage by forming their own community, based on Japanese language, customs and culture. A special long-term visa was granted by a revision of the 1990 Immigration Control and Refugee Recognition Act, while Japan's ambiguous stance left the main issue of its labour shortage unresolved. However, despite their Japanese descent, it turned out that these nikkeijin faced a variety of difficulties in Japan because they lacked fluent Japanese language skills and knowledge of Japanese social customs.

The movement of migrant workers from the Philippines also continues, despite the decline in the number of entertainment visas (for singers, actors and other performers) issued by the Japanese government, establishing it as one of the largest minority populations. It can 
be argued that the presence of the large Filipino population is due to its long tradition of migration to Japan, together with intermarriage. This is partly due to the number of women working in Japan since the late 1970s as entertainers or bar hostesses, while a large number of Filipino men have come to Japan as manual laborers. ${ }^{10}$

TABLE 1. Healthcare Worker Candidates From Indonesia, the Philippines and Vietnam, August 2008 to July 2014

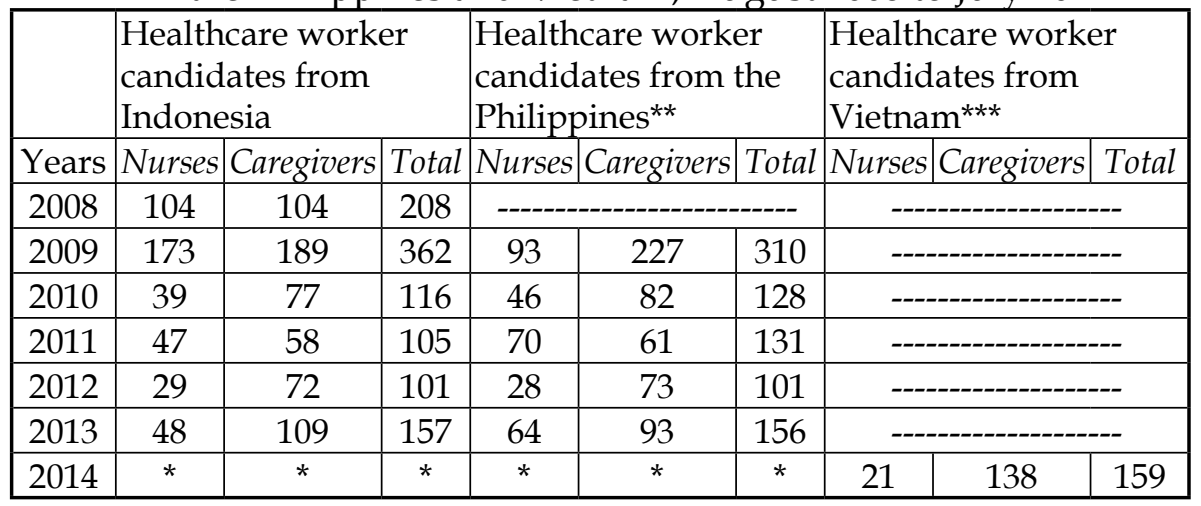

Source: Ministry of Health, Labour and Welfare. ${ }^{12}$ Table constructed by the author. * The Ministry of Health, Labour and Welfare has not revealed the number of healthcare worker candidates from Indonesia and the Philippines who came to Japan in 2014. **Filipino healthcare migrant worker candidates started to come to Japan in 2009. ***Vietnamese healthcare migrant worker candidates started to come to Japan in 2014.

In the case of Indonesian, Filipino and Vietnamese nurse and caregiving worker candidates, a total of 2,377 individuals came to Japan between 2008 and 2014 (The first group of Indonesian healthcare candidates came to Japan in 2008). ${ }^{11}$ However, some may already have left Japan. As elaborated below, Southeast Asian healthcare worker candidates are asked to return to their home country if they do not pass Japan's national examination.

As shown in Table 1, the Japanese government has accepted Southeast Asian healthcare workers as candidates each year. It is assumed that the low number of healthcare worker candidates in 2012 was caused by the impact of the 2011 Great East Japan earthquake in March 2011. The Japanese government introduced a similar scheme for Vietnam, to attract more healthcare worker candidates under the free trade agreement: the Japan-Vietnam Economic Partnership Agreement (JVEPA) in 2012, and a group of Vietnamese came to Japan in July 2014. ${ }^{13}$

All Southeast Asian healthcare worker candidates are asked to follow domestic regulations along with Japanese nurses and caregivers to pass 
a Japanese-language based examination. The Ministry of Health, Labour and Welfare has firmly stated that accepting nurse and caregiving worker candidates from Indonesia, the Philippines and Vietnam is not related to a shortage of domestic workers in the healthcare industries, but is a move to accommodate requests from those countries. The ministry claims that in this way it aims to enhance economic ties between Japan and its counterparts. ${ }^{14}$

In my view, the statement above by the Ministry of Health, Labour and Welfare is a good example of on-stage tatemae talk with mixed messages offered to liberal Japanese officials and their Southeast Asian counterparts. The ministry could be concerned about the incorporation of non-Japanese migrant workers into Japanese society in respect to Japanese ideology, supported by conservative Japanese officials, business elites and other influential figures who question how many Southeast Asian healthcare workers would be deemed socially and culturally 'appropriate' to come and join Japan's labour market, given the needs of Japan's rapidly aging population. The ministry may accept a certain number of overseas healthcare workers each year, but strict regulations restrict the length of their stay.

\section{Japan's Healthcare Industry}

As stated above, 25.7 per cent of the total population of Japan was over the age of 65 as of July $2014 .{ }^{15} \mathrm{~A}$ further 61.5 per cent were between 15 and 64 , and only 12.8 per cent were below the age of 14 (Japan's population pyramid has an inverted structure). Coulmas has acknowledged that Japan is not just a middle-aged country but is becoming a hyper-aging country in which a fifth or more of the population is over 65 years old (2007: 4-5). Why is Japan still hesitant to discuss opening the door to the international labour market?

As one of the world's most developed and rapidly aging societies, Japan's healthcare issues are complex. The healthcare industry continues to suffer from a shortage of qualified workers. With a rapid increase in the number of Japanese elderly in hospitals and healthcare facilities, nursing and caregiving service sectors are overstretched. Because of the nature of the healthcare industry in Japan, with long hours, often unpleasant work and low salaries, not many people apply for vacant positions and existing workers choose not to keep their jobs for long. Caregivers also need to have social skills to interact with the elderly and help them with meals, bathing and using the toilet. ${ }^{16}$ These jobs are 
quite demanding for new employees, who often join just to earn money or to fill in between permanent jobs.

The healthcare industry continues to offer a poor working environment, with long hours and frequent night shifts. According to the Ministry of Health, Labour and Welfare, the average salary of a caregiver is 210,000 Yen per month, much lower than the average salary for all industries of 330,000 Yen. ${ }^{17}$ Yasuhiro Yūki, an assistant professor in the School of Social Welfare at Shukutoku University, argues that because of the relatively low salaries, many workers choose different jobs, despite their desire to work in the industry. ${ }^{18}$ The ministry also found that there has been a decline in applicants to study for the national license exam in universities and colleges for the last few years. Compared with the capacity of caregiver courses at universities and colleges, the percentage of students recruited decreased from 72.0 per cent in 2006, to 64.0 per cent in 2007, and 46.0 per cent in $2008 .{ }^{19}$ Even if they have passed the national exam, their family members, as well as some career counsellors, sometimes discourage candidates from working in the healthcare industry because of these fundamental problems and issues: low salaries and unsociable working hours.

Officials from the Ministry of Heath, Labour and Welfare estimated that the Japanese would require at least an additional 400,000 to 600,000 working nurses and caregivers by $2014 .^{20}$ There is also a high demand for in-home caregivers, and always a serious shortage of labour. The officials of the ministry estimated that Japan would eventually need a total of approximately 7.8 million nurses and caregivers by $2025 .{ }^{21}$ Thus, the increase in Japan's aging population does not seem to be slowing down.

\section{Indonesian Caregiving Workers}

This section focuses on Indonesian caregiving candidates under the JIEPA free trade agreement. The first group of candidates arrived in Japan in August 2008 and were the first cohort to train in Japan (2008 - 2011) and take the Japanese-language examinations. The 2008 arrival of Indonesian nurse and caregiver candidates caused mixed reactions, and they faced a series of obstacles when going on to work in retirement homes and hospitals.

Under JIEPA, Japan agreed to accept a total of 400 nurses and 600 caregivers in July 2008 for the next two years. In August 2008, 208 nursing candidates and caregiver candidates arrived in the first group (104 candidates of each type). In the following year, 362 candidates (173 
nursing candidates and 189 caregiver candidates) decided to try to work in Japan (see Table 1). Unlike foreign students, foreign nurses and caregivers are carefully selected by the Japanese government, which has given a public assurance that the incorporation of foreign caregivers and nurses will not have any negative impact on the domestic labour market (Cortez 2010: 193). Japan's official confidence may be supported by the fact that all Indonesian candidates have to follow Japanese domestic regulations for nurses and caregivers, as they need to pass a Japaneselanguage based examination to become Japanese-standard certified nurses and caregivers. ${ }^{22}$ Under the agreement, the candidates have six months for language training before being dispatched to hospitals or healthcare centres in Japan. ${ }^{23}$ In the case of nursing candidates, they have three years of training, during which they have three chances to pass the national exam while working in the selected hospitals and nursing facilities. ${ }^{24}$ The caregiver candidates have up to four years to complete their training, but they are required to have three full years of work experience in Japan prior to taking the national exam. Thus, they can only take the exam in the final year and only have one shot to pass it. All candidates will have to return to their home country if they do not pass the exam. Besides this pressure, they obviously face language and cultural barriers when working with elderly Japanese clients, managers, colleagues and others in their assigned hospitals or facilities.

Following their arrival, there was intense cultural apprehension from many people in the healthcare industry. Some hospitals and nursing facilities did not see the acceptance of foreign workers as a positive decision. ${ }^{25}$ A representative of a specialist nursing home in Tokyo said 'we are not certain how well foreigners will be accepted in care giving service centres because of their cultural differences. Some family members of the patients are also concerned about this issue. There may not be enough benefits to accept Indonesian caregivers'. ${ }^{26}$ There was also an economic risk involved with accepting foreign caregiver candidates: Yūko Hirano, an assistant professor, argued that 'the main problem is high cost. Nursing facilities and hospitals have to pay around 600,000 Yen for each candidate's transportation cost, tuition for Japanese language training and some other costs'. ${ }^{27}$

Some Japanese managers and workers in hospitals and nursing facilities found more serious problems after accepting foreign candidates. The Asahi Shinbun, the second most widely-circulated Japanese newspaper after the Yomiuri Shinbun, conducted an independent survey on foreign caregiver trainees and the Japanese language based national exam 
between late September and early October 2009 in 47 hospitals and 53 nursing facilities that trained Indonesian candidates in Japan: 86 of these yielded valid responses. ${ }^{28}$ According to the survey, 71 respondents wished to change the Japanese-language based national exam system for foreign candidates because it was too challenging. Of these, 32 respondents said that the usage of Kanji (Chinese characters) was quite difficult, and that additional explanatory Hiragana (Japanese phonetic characters) should be added to the exams. Twenty-eight respondents said that they should take the exam in English or their native language, while some wanted the government to extend their period of stay in Japan so that they would have more chances to pass the exam. Their argument for special treatment was that many of the foreign candidates were either trained or certified nurses and caregivers in their home countries. The survey raised the general question of how foreign candidates could pass the Japanese language-based national exam. There was also a shared problem among most hospitals and nursing facilities that they did not have appropriately-trained staff members to teach the foreign candidates Japanese language skills.

After three years training, 94 Indonesians and one Filipino took the national examination for caregiving workers in 2012, and 36 of these passed the national examination (37.9 per cent)..$^{29}$ The Filipino who passed the national exam was an independent candidate who had previously worked in Japan and didn't arrive via the programme. But, by July 2012, 8 of the 35 Indonesians who had passed the exam had quit and left the country. According to Professor Kiyoshi Adachi from Kyushu University, who organized a research team to conduct a survey for Indonesian caregiver worker candidates, not all of the candidates were interested in staying and working in Japan for a long time: some just wanted to gain some work experience and return to their families in Indonesia. ${ }^{30}$ Adachi also noted that some of them sensed that they were not welcomed by Japanese society.

In the following two years, 86 out of 184 Indonesians and 42 out of 133 Filipino candidates passed the national examination in 2013. 46 out of 107 Indonesians and 32 out of 108 Filipino candidates passed it in 2014. ${ }^{31}$ Overall, just a few Southeast Asian healthcare worker candidates have been allowed to work in Japan as certified caregivers since 2012, even though the healthcare industry still suffers from a shortage of Japanese nurses and caregivers. My research suggests that some hospitals and healthcare facilities are still concerned about possible communication problems between the Japanese workers/clients and the foreign 
workers. They are only willing to accept foreign nurse and caregiver candidates as new trainees if they have no other option.

I believe that the government has taken a conservative approach to this issue for cultural reasons; they are aware that some Japanese are showing more interest in the healthcare industry since employment opportunities became more restricted following the 2008 financial crisis. The government may still believe that Japanese elders should be taken care of by Japanese nurses and caregivers. But with long hours and low salaries, not many Japanese apply for vacant positions, and existing workers choose not to keep their jobs for long (Takumi 2014). As noted, healthcare is one of the least favoured industries and it is quite possible that elderly and their family members will soon be unable to hire the necessary nurses and caregivers.

\section{Conclusion}

My research has shown that the inflow of Southeast Asian healthcare worker candidates has been caught up within the ideological identity of the Japanese people as they struggle to engage with the process of globalization. The reluctance to receive foreign workers is typical of conservative Japanese politicians and intellectuals who do not want Japan to become an immigrant-receiving society, as Canada or the United States have been. ${ }^{33}$ Their view is that long-term migrant workers, like the nikkenjin, do not adequately fulfil their roles in Japan: they are not able to keep their jobs, to learn Japanese language and culture, to get along with their neighbours, to pay national insurance and to send their children to school (Terakura 2008: 81-83). This is a challenge for non-Japanese migrants who work as contract workers with low wages and do not have the free time to learn Japanese language and culture or socialize with their Japanese neighbours.

Japanese is split between a group of nationalist policymakers, scholars and influential figures who believe that Japan should focus on the importance of internal communal unity and domestic issues, and that it would even be better to isolate Japan from the rest of the world, using a sakoku ideology, and the global kaikoku thinkers, who are more interested in relaxing Japan's immigration policy and seeing fuller integration into the international community. The debate between the rival ideologies of sakoku and kaikoku seems to continue. However, this article does acknowledge that there are some politicians, educators and healthcare workers who attempt to improve the Japanese healthcare industry by 
giving international migrants better access to living and working in Japan. They argue that the healthcare industry should globalize like other industries because of the constant shortage of Japanese workers, mainly caused by its rapidly aging population.

This article showed how deeply embedded cultural ideologies, such as the concept of the family system, inner/outer (uchi/soto), front/back (omote/ura), and on-stage/off-stage (tatemae/honne), influence decisionmaking at the political level via the EPA agreements, as well as at the societal level in terms of relations between the Japanese people consisting of healthcare staff, clients/families and non-Japanese healthcare migrants. The Japanese government has been extremely careful with regard to international migrants, questioning whether or not foreigners can live with the Japanese. The Japanese government has accordingly set high standards for Southeast Asian nurse and caregiver worker candidates, and this has limited inflow overall.

Southeast Asian healthcare workers may not be as patient as the Japanese government. Under the agreement, Japan has opened its doors for Indonesian, Filipino and Vietnamese nurses and caregivers, but the language barrier is set too high and some candidates may choose to seek work elsewhere.

I propose that in order to sufficiently support the development of Japan's healthcare industry, the regulations for Indonesian, Filipino and Vietnamese nurse and caregiver candidates need to be revised. Perhaps, Japan's national examination could be translated into English to make it more accessible for many certified nurses and caregivers in their home countries. Caregiver worker candidates should be able to stay in Japan for six years instead of four years so that they would have more chances to pass the Japanese-language based examination. The examination should be designed to cover the basic aspects of being nurses and caregiver workers, and to test their knowledge of technical skills, besides Japanese language skills.

Furthermore, the healthcare industry should change its working environment to attract domestic healthcare workers: shorter working hours and higher salaries. Even if the Japanese government supports all these changes, it still faces a huge challenge.

Finally, I want to address questions about the issues, concerns and interests that emerge for the Japanese, and what are Japanese reactions to the possibility of increasing ethnic and cultural diversity? Most of the issues and concerns relate to the social behaviour of migrant workers: whether they can keep their jobs, learn Japanese language and culture, 
and get along with their neighbours. People are concerned not only with how well Southeast Asian healthcare workers do their jobs, they also want to know whether they can become part of Japanese society. The Ministry of Health, Labour and Welfare might have accepted nurse and caregiving worker candidates from Indonesia, the Philippines and Vietnam to enhance economic ties between Japan and its counterparts, but the total numbers of healthcare workers have been limited because of the possibility of social costs. A relative low number of Southeast Asians have arrived in Japan, and only a few have been able to pass the national examination and work as certified workers. There have been relatively few major reactions by Japanese society against the inclusion of foreign nurse and caregiver candidates, though the Japanese media is particularly interested in talking about how well non-Japanese healthcare worker candidates get along with Japanese co-workers and clients or whether or not they accept Japanese culture. The reality is that there have been very small groups of nurse and caregiver worker candidates coming to Japan from Southeast Asian countries, in comparison to the number of students, technical trainees and other business people from China. Since 2012, there has been a decrease in the number of Japanese newspaper and magazine articles discussing Southeast Asian healthcare worker candidates in Japan. Perhaps, the Japanese media, particularly those with conservative leanings, have realized that a small group of Southeast Asian healthcare workers will not pose as a 'threat' to Japanese society.

Kenji KANEKO received his PhD (2012) in Asia Pacific Studies from the Ritsumeikan Asia Pacific University, Japan. He currently holds a postdoctoral research scholarship at the Centre for Modern Languages and Literature in Faculty of Creative Industries at Universiti Tunku Abdul Rahman, Malaysia. Email:kenjka07@gmail.com

\section{NOTES}

1 The terms 'culture' and 'behaviour' are difficult to define because they have been used in so many different ways by scholars and in everyday speech. In sociology, Anthony Giddens defines culture as one of the most distinctive properties of human social association, including the set of shared values and rituals (Giddens 2009: 1115).

2 Another term, kokusaika (internationalization), was commonly used before the beginning of the 1990s to promote multiculturalism in Japan. The two terms are often used interchangeably.

3 Ministry of Internal Affairs and Communications, Statistic Bureau 2014. 'The result of the population estimate, Monthly report'. http://bit.ly/1jNDqqA. Accessed 6 
December 2014.

4 Peter Dale sees nihonjinron as a potential threat to academic studies of the Japanese. Dale argues that most nihonjinron literature attempts to 'define the specificity of Japanese identity, and range over the whole complex of Japanese historical culture, choosing illustrative materials from classical records, folklore materials, historical chronicles, contemporary news, dictionaries of Japanese usage etc.'. (1986: Introduction).

5 Japan has been described as tan'itsuminzoku kokka, a mono-ethnic nation (see Oguma 1995).

6 Ministry of Justice 2014. 'Heisei 26 nen 6 gatsu matsu genzai ni okeru zairyu gaikokujin ni tsuite (kakuteichi) (About the number of registered foreigners in Japan as of the end of July 2014) (final estimate))'.. http://bit.ly/1P0XxiW. Accessed 3 December 2014.

7 Japan has its own minority group consisting of Koreans and Chinese who came to Japan as colonial subjects before 1945. They hold tokubetsu eijyūsha kyokasho (special long-term resident visas). They are generally called zainichi gaikokujin (resident foreigners).

8 It is interesting to note that a good number of the Chinese who were educated in Japanese universities have successfully secured better paying employment despite Japan's political and historical issues with China.

9 Japanese descendants had returned to Japan before the revision of the Immigration policy, but a greater number of nikkeijin arrived in Japan after 1990.

10 It is important to note that the number of entertainment visas issued in Japan have declined due to concerns with Filipino migrants' human rights.

11 Ministry of Health, Labour and Welfare 2014a. 'Indoneshia, firipin, betonamu kara no gaikokujin kangoshi, kaigofukushishi kouhoshano ukeire ni tsuite (About hosting nurse and caregiver worker candidates from Indonesia, the Philippine and Vietnam)'. http:/ / bit.ly/1O4pas4. Accessed 3 December 2014.

12 Ministry of Health, Labour and Welfare 2014b. Ministry of Health, Labour and Welfare 2013a. 'Firipin jin kangoshi, kaigofukushishi kouhoshano ukeire ni tsuite (About hosting Filipino nurse and caregiver worker candidates) (in Japanese)'. http:// www.mhlw.go.jp/bunya/koyou/other07/index.html . Accessed 3 December 2014. Ministry of Health, Labour and Welfare 2013b. 'Indoneshia jin kangoshi, kaigofukushishi kouhoshano ukeire ni tsuite (About hosting Indonesian nurse and caregiver worker candidates)'. http:/ / bit.ly/1Jy2mJv. Accessed 3 December 2014.

13 Ministry of Health, Labour and Welfare 2014b. 'Betonamu jin kangoshi, kaigofukushishi kouhoshano ukeire ni tsuite (About hosting Vietnamese nurse and caregiver worker candidates)'. http:/ / bit.ly/1YJJkuU. Accessed 3 December 2014.

14 Ministry of Health, Labour and Welfare 2014a. Idei's article shows a different perspective: Idei, Yasuhiro 2012 April 4. 'Konpon ga machi gakkeiru 'gaikokujin gaiko' mondai (Getting it wrong from the beginning: foreign caregiver problems)'. Shinchosha: Foresight. http:// www.fsight.jp/11347 . Accessed 9 September 2015.

15 Ministry of Internal Affairs and Communications, Statistic Bureau, 2014.

16 Tokyo Shinbun 19 August 2007. 'Kaigo shokuba no jinzaikakuho 2014 nen ni 140 man- 160 man nin no rōdōsha ga hitsuyō: No 169 (Caregiver service will require 1.4 to 1.6 million workers in 2014: No. 169)'. http:/ / bit.ly/1LWMLVJ. Accessed 9 October 2009. Wedge Infinity 20 February 2009. 'Kaigo, nōgyō o bakani suruna (Do not look down on caregiving and farming)'. http:// bit.ly/1FvomKi. Accessed 25 May 2010. See also Takumi 2014: 60-61.

17 Wedge Infinity 20 February 2009. See also Takumi 2014: 54, 55-57 and 60-61.

18 Wedge Infinity 20 February 2009. See also Takumi 2014: 60-61. 
19 Wedge Infinity 20 February 2009. See also Takumi 2014: 58-61 and 65-67.

20 Obara, Sawako 27 August 2008. 'Indonesia caregivers land contracts'. The Japan Times. http://www.japantimes.co.jp/text/nn20080827f2.html . Accessed 1 November 2009. See also Takumi 2014: 65-67.

21 Obara, Sawako 27 August 2008.

22 Agnote, Dario 20 December 2008. 'Filipino caregivers face hurdles'. The Japan Times. http://www.japantimes.co.jp/text/nn20081220f2.html . Accessed 1 November 2009.

23 This Japanese language condition may be exempted if candidates already have appropriate Japanese language skills.

24 Sogo, Tomoko, Miyazaki, Sonoko and Morimoto, Miki. 3 November 2009. 'Survey: $70 \%$ want special exams for Indonesian trainees'. The Asahi Shinbun. http:// www.asiaviews.org/regional-news/2-regional-news-a-special-reports/20339reportalias1514. Accessed 18 November 2012.

25 Sankei Shinbun 1 May 2009. 'Indonesia jin kaigoshi kangoshi ukeire ni shōkyoku shisei (Hesitant to accept Indonesian caregiver and nurse candidates).' http:/ / sankei. jp.msn.com/life/welfare/090501/wlf0905010803001-n1.htm . Accessed 28 April 2010.

26 Sankei Shinbun 1 May 2009.

27 Kato, Mariko 29 January 2010. 'Guiding hard for Indonesian nurses'. The Japan Times. http:// bit.ly/1MAij6r. Accessed 28 April 2010.

28 Sogo, Tomoko, Miyazaki, Sonoko and Morimoto, Miki. 3 November 2009.

29 Ministry of Health, Labour and Welfare 28 March 2012a. 'Dai 24 kaigo fukushi shi kokkashiken ni EPA kaigo fukushi shi kōhosha 36 mei ga goukakushimashita (36 EPA caregiver worker candidates passed the 24th caregiving worker national examination)'. http:/ / bit.ly/1GbI6xe. Accessed 1 November 2012.

30 Adachi, Kiyoshi 24 July 2012. 'Kikoku suru gaikokujin kaigo fukushi-shi (Foreign caregiving workers going back to their home country)'. Chūgoku Shinbun.

31 Ministry of Health, Labour and Welfare 27 March 2014c. 'Dai 26 kai kaigo fukushi shi kokka shaken ni okeru EPA kaigo fukushi shi kōhosha no shiken kekka (The result of the 26th caregiver national examination among EPA caregiver worker candidates)'. http:/ / bit. ly/1jpv7TD. Accessed 1 December 2014.

32 Ministry of Health, Labour and Welfare 28 March 2012b. 'Dai 24 kaigo fukushi shi kokkashiken gōkakusha happō (presenting those who passed the 24th caregiving worker national examination'. http:/ / bit.ly/1iVH4k5. Accessed 1 November 2012. Ministry of Health, Labour and Welfare 29 March 2011. 'Dai 23 kaigo fukushi shi kokkashiken gōkakusha happō (presenting those who passed the 23th caregiving worker national examination'. http:/ / bit.ly/1KF6co9. Accessed 1 November 2012.

33 See also Yaezakura no kai 2014 September. Teigen 'Imin, gaikokujin rōdōsha ni tayorazuni keizai seichō suru nihon' (Proposal 'Japan should be a country that is not able to relay no migrants or migrant workers for its economic growth'). Imin, tamin zoku kyōsei ni hantai suru kai. (The association of Japanese nationals against immigration and multicultural policies). http://mikoup.ebb.jp/src/file1582.pdf . Accessed 9 September 2015. See Jisedai no tō (The party for future generations) 2014. http://jisedai.jp/. This is a conservative political party, associated to Shintaro Ishihara (former Tokyo mayor).

34 See Menju, Toshihiro 2015. 'Tekisetsu na imin no ukeire wa nihon no mirai ni tsunagaru (Appropriate immigration policies lead to Japan's bright future: Innovation and better evaluation by the world)'. NewSphere. http:/ / newsphere.jp/national/20150303-imin2/ . Accessed 9 September 2015. 


\section{REFERENCES}

Brody, Betsy Teresa 2002. Opening the Door: Immigration, Ethnicity, and Globalization in Japan. London: Routledge.

Chen, Tien-shi 2008. 'The Increasing Presence of Chinese Migrants in Japan'. In S. Yamashita., M. Minami., D. W. Haines., and J. S. Eades (eds.), Transnational Migration in East Asia. Osaka: National Museum of Ethnology: 39-52.

Coulmas, Florian 2007. Population Decline and Ageing in Japan: the Social Consequence. New York: Routledge.

Cortez, Michael Angelo A 2010. 'Migration Under the Japan-Philippines Free Trade Agreement'. In K. Pookong., and H. Yoshimatsu (eds.), Global Movements in the Asia Pacific. London: World Scientific: 181-200.

Dale, Peter 1986. The Myth of Japanese Uniqueness. London: Routledge and Nissan Institution for Japanese Studies, University of Oxford.

Furukawa, Kojun, Sato, Toyomichi, and Okuda, Isayo (eds.) 1996. Kaigo Fukushi (Caregiving Workers). Tokyo: Yuhikaku.

Giddens, Anthony 2009. Sociology: Sixth edition. Cambridge: Polity Press.

Hendry, Joy 1995. Understanding Japanese Society, Second Edition. New York: Routledge.

Herbert, Wolfgang 1996. Foreign Workers and Law Enforcement in Japan. London and New York: Kegan Paul International.

Oguma, Eiji 1995. Tanitsuminzokushinwa No Kigen: The Myth of the Homogenous Nation (in Japanese). Tokyo: Shinyōsha.

Rosenberger, Nancy R. 1992. 'Tree in Summer, Tree in Winter: Movement of Self in Japan'. In N. R. Rosenberger (ed.), Japanese Sense of Self. New York: Cambridge University Press: 67-92.

Sugimoto, Yoshio. 2010. An Introduction to Japanese Society. Third edition. Cambridge: Cambridge University Press.

Takumi, Isao 2014. 'Kaigo Shokuin No Hitode Busoku Mondai (A shortage of Caregiving Workers) (in Japanese)'. Meiji Yatsuda Institute of Life and Wellness: Research Reports 88: 54-69.

Taguchi, Sumikazu. 1983-1984. 'A Note on Current Research of Immigrant Groups in Japan'. International Migration Review 17(4): 699-714.

Terakura, Kenichi 2008. 'Shutsunyūkoku Kanriseido O Meguru Tōmen No Shuyō Kadai (Major Challenges in the Immigration System)'. In Jinkōgenshō Shakai No Gaikokujin Mondai Sōgō Chōsa (Comprehensive Survey on Foreigners 'Problems' in the Aging Society). National Diet Library: Chōsa Shiryō (data files): 77-89.

Tsuda, Takeyuki 1999. 'Transnational Migration and the Nationalization of Ethnic Identity Among Japanese Brazilian Return Migrants'. Echo 27(2): 145-179.

Yoshino, Kosaku 1992. Cultural Nationalism in Contemporary Japan: A sociological Enquiry. New York: Routledge. 